\title{
Determination of migratory dynamics of the sooty shearwater in the Pacific using stable carbon and nitrogen isotope analysis
}

\author{
Hiroshi Minami*, Haruo Ogi \\ Research Institute of North Pacific Fisheries, Faculty of Fisheries, Hokkaido University, 3-1-1 Minatocho, Hakodate, \\ Hokkaido 041, Japan
}

\begin{abstract}
Migratory dynamics and dietary change of sooty shearwaters Puffinus griseus sampled in the North Pacific from May to September in 1990 and 1991 were investigated using the method of $\delta^{13} \mathrm{C}$ and $\delta^{15} \mathrm{~N}$ analyses. $\delta^{13} \mathrm{C}$ and $\delta^{15} \mathrm{~N}$ values of muscle tissues of shearwaters ranged from -21.9 to $-15.1 \%$ and from 8.1 to $16.6 \%$, respectively. The $\delta^{15} \mathrm{~N}$ values of immature shearwaters collected east of longitude $170^{\circ} \mathrm{W}$ differed from those west of this longitude. In the northwestern Pacific, $\delta^{13} \mathrm{C}$ and $\delta^{15} \mathrm{~N}$ of both mature and immature birds were lowest in May (both mature and immature: $\delta^{13} \mathrm{C}-20.7 \pm 0.9 \%$, $\delta^{15} \mathrm{~N} 8.8 \pm 1.0 \%$; mean $\pm \mathrm{SD}$ ) and then gradually increased until early summer. In contrast, no seasonal variations in $\delta^{13} \mathrm{C}$ and $\delta^{15} \mathrm{~N}$ of mature birds were observed in the northeastern Pacific and $\delta^{13} \mathrm{C}$ and $\delta^{15} \mathrm{~N}$ of immature birds in the northeastern area were the highest in May $\left(\delta^{13} \mathrm{C}-15.9 \pm 0.5 \%, \delta^{15} \mathrm{~N} 15.9 \pm\right.$ $0.8 \%$; mean \pm SD), and then gradually declined. We attribute these isotopic trends primarily to differences in the isotopic signatures of food-web components due to oceanographic factors, and the influence of sooty shearwater migrations. Low or high $\delta^{13} \mathrm{C}$ and $\delta^{15} \mathrm{~N}$ values of immature and mature shearwaters in the western and eastern North Pacific in May may be caused by the transient effects of food consumed in the Southern Hemisphere before or during the northward migration. In particular, the high $\delta^{15} \mathrm{~N}$ of the immature birds in the northeastern area seems to be caused by feeding on ${ }^{15} \mathrm{~N}$ rich diets in the eastern tropical Pacific, off Peru and California, during the northward migration, where occurrence of denitrification with a high nitrogen isotope fractionation factor of up to 1.04 is well known. The pattern of the migratory behaviour of sooty shearwaters in the Pacific Ocean was successfully clarified by their isotopic signature.
\end{abstract}

KEY WORDS: Puffinus griseus · Stable isotope · Carbon $13 \cdot$ Nitrogen $15 \cdot$ Migration

\section{INTRODUCTION}

Seabird species, especially those of large populations with high biomass and extensive distributions, are important indicators of ecological phenomena occurring in marine environments. Studies to determine their distributions, diets, and trophic relationships can thus help us to elucidate characteristics of the food-web structures in marine ecosystems. However, detailed ecological studies of seabirds in the open

\footnotetext{
'Present address: Division of Environmental Chemistry, National Institute for Environmental Studies, 16-2 Onogawa, Tsukuba, Ibaraki 305, Japan. E-mail: hminami@nies.go.jp
}

ocean are quite difficult because of the logistical difficulty in obtaining information about them.

The sooty shearwater Puffinus griseus comprises about 20 to $50 \%$ of seabird numbers and about 30 to $70 \%$ of seabird biomass in the subarctic North Pacific in summer (Sanger \& Ainley 1988). This seabird dominates the North Pacific avifauna in summer and is extensively distributed over oceanic regions between $40^{\circ}$ and $55^{\circ} \mathrm{N}$ (Ogi et al. 1981, Guzman \& Myres 1983, Ogi 1984, Briggs \& Chu 1986). Sooty shearwaters breed mainly around New Zealand, southeastern Australia, and southern South America from September to April (Marchant \& Higgins 1990). In the non-breeding season, most of the population migrates to the North Pacific, but some birds migrate to the North Atlantic or 
remain in the Southern Hemisphere (Marchant \& Higgins 1990). Shuntov (1972) showed that the birds breeding in the New Zealand or southeastern Australia areas migrate along the western North Pacific. In contrast, sooty shearwaters from the southern South American breeding grounds migrate along the eastern North Pacific (Shuntov 1972). Most adults depart breeding islands by the second week of April, with a few remaining until May (Marchant \& Higgins 1990). Chicks remain for up to a month longer before leaving (Marchant \& Higgins 1990). The western Pacific population arrives at the east of northern Japan by late May, while the eastern Pacific population reaches southern California by May (Marchant \& Higgins 1990). Little information exists on the migratory behaviour of the sooty shearwater (Shuntov 1972).

Stable isotope analysis can be used to determine diet and trophic level of an animal. It is well known that the stable nitrogen isotope ratio shows a stepwise enrichment along trophic levels in marine ecosystems (DeNiro \& Epstein 1978, Wada et al. 1987, Fry 1988, Hobson \& Welch 1992). Consequently, nitrogen isotope ratios in animals reflect the trophic levels within food chains, increasing by 3 to $4 \%$ per trophic level (DeNiro \& Epstein 1981, Minagawa \& Wada 1984). In contrast, animal $\delta^{13} \mathrm{C}$ is quite close to that of its corresponding diet (DeNiro \& Epstein 1978). Since the turnover time of diet in the tissues of consumers changes according to the metabolic rates of each tissue (Thompson 1953), stable isotope analysis of each tissue can thus provide different time-integrated dietary information (Hobson 1993). In laboratory studies of stable isotope turnover rates in birds, the half life of carbon in muscle tissues of Japanese quails Coturnix japonica was 12.4 d (Hobson \& Clark 1992a). Although the turnover rates of carbon and nitrogen in muscle tissues of wild birds are unknown, stable isotope ratios of muscle tissue are considered to reflect the diet of at least the previous few weeks. Consequently, by analyzing stable isotopes in the tissues of seabirds, dietary information over a few weeks can be obtained. In this sense, stable isotope analysis provides time integrated and quantitative information on food habits and migratory mechanisms of seabirds in the open ocean. Stable isotope analysis of particulate organic matter (POM) and various organisms also helps to reveal trophic relationships.

Recently, stable isotope analysis has been used to determine trophic relationships and diets of seabirds (Hobson 1987, 1990, 1991, 1993, Mizutani et al. 1990, Hobson et al. 1994). However, changes in the stable isotope signatures of seabirds during their migrations have not yet been thoroughly studied (Minami et al. 1995). According to Schell et al. (1989), stable isotope analyses of bowhead whale Balaena mysticetus baleen provided useful indicators of variations in regional habitat usage and seasonal changes in diet.

The $\delta^{13} \mathrm{C}$ and $\delta^{15} \mathrm{~N}$ in muscle of extensive migratory seabirds should vary, depending upon the regional changes in those of their prey organisms, which are further affected by regional oceanographic factors (Minami et al. 1995). The Pacific Ocean has unique characteristics with respect to the distribution and variation of phytoplankton $\delta^{15} \mathrm{~N}$. According to Wada \& Hattori (1991), the western part of the ocean involving the south and east China Sea is characterized by the occurrence of cyanobacteria Trichodesmium spp. which have $\delta^{1.5} \mathrm{~N}$ values as low as $-2 \%$ due to molecular nitrogen fixation. In contrast, highest $\delta^{15} \mathrm{~N}$ values up to $10 \%$ are well known for phytoplankton in the eastern tropical Pacific Ocean, where a huge amount of denitrification occurs in the intermediate oxygendeficient water mass accompanied by a large isotope fractionation factor of up to 1.04 (Cline \& Kaplan 1975). These geographical values of $\delta^{15} \mathrm{~N}$ can thus provide a useful key to clarify the migratory behaviour of sooty shearwaters.

In this study we measured the stable carbon $\left(\delta^{13} \mathrm{C}\right)$ and nitrogen $\left(\delta^{15} \mathrm{~N}\right)$ isotope ratios of muscle tissue of sooty shearwaters to elucidate their feeding behaviour and dietary changes during northward migrations in the North Pacific. The accurate evaluation of temporal and geographic variations of seabird diets by using stable isotopes was also performed to provide a significant advance in using seabirds as bio-indicators of marine ecosystems.

\section{MATERIALS AND METHODS}

Sampling locations and growth stages. The pectoral muscle tissues of the 87 sooty shearwaters used for the stable isotope analysis were obtained from birds which had become entangled in gill nets set for squid in the North Pacific $\left(35^{\circ} 16^{\prime}\right.$ to $46^{\circ} 30^{\prime} \mathrm{N}, 150^{\circ} 07^{\prime} \mathrm{E}$ to $150^{\circ}$ $27^{\prime}$ W; Fig. 1) from May through September during 1990 and 1991. Some of the sooty shearwater $\delta^{13} \mathrm{C}$ and $\delta^{15} \mathrm{~N}$ data came from a report by Minami et al. (1995). Birds were classified as mature or immature based on the shapes and sizes of sex organs (Shiomi 1993) and the existence of the Bursa of Fabricius (Shiomi 1993). Birds 1 to 2 yr of age were categorized as immature, while birds of 3 yr and older were considered mature. First pairing of sooty shearwater probably occurs at 3 to $4 \mathrm{yr}$, but possibly this bird does not breed until between 5 and 7 yr (Richdale 1963).

Stable isotope measurements. Muscle tissue from sooty shearwaters was ground into a fine powder after lipid was extracted using a 2:1 chloroform:methanol solution. The procedures for analyzing carbon and 


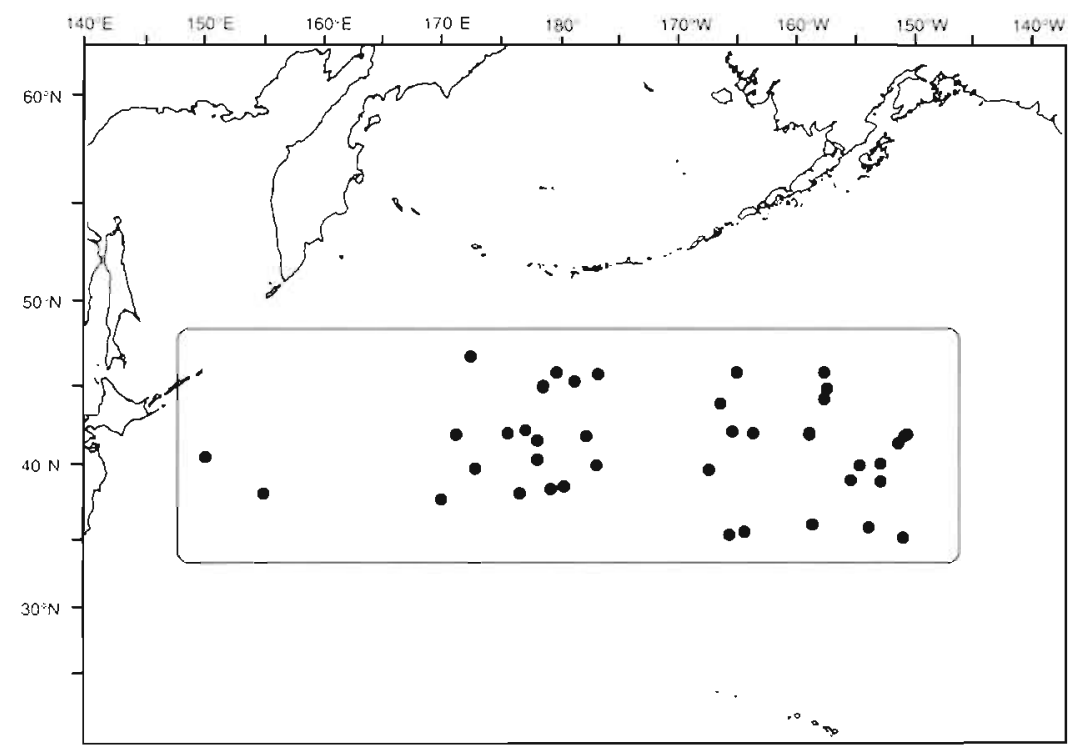

Fig. 1 Sampling locations of sooty shearwater in the North Pacific from May through September in 1990 and 1991 east and west of longitude $170^{\circ} \mathrm{W}$ in the North Pacific was clear. The carbon isotope ratios of immature birds collected east of longitude $170^{\circ} \mathrm{W}$ were somewhat higher than those of birds in the west. Therefore, the North Pacific populations of this species were classified into 2 distinct groups: the northwestern and northeastern Pacific populations, divided by longitude $170^{\circ} \mathrm{W}$

The mean $\delta^{13} \mathrm{C}$ and $\delta^{15} \mathrm{~N}$ values of immature birds in the northwestern area were $-18.7 \pm 1.2$ and $10.6 \pm 1.8 \%$, respectively (mean $\pm \mathrm{SD}$ ). In the northeastern area, the corresponding isotope values of immature birds were $-16.7 \pm 1.4$ and $15.2 \pm 1.1 \%$, respectively. Immature birds in the northeastern area exhibited significantly higher $\delta^{13} \mathrm{C}$ and $\delta^{15} \mathrm{~N}$ values than those in the northwestern area (C: $\mathrm{p}<0.05$; $\mathrm{N}: \mathrm{p}<0.01$; Mann-Whitney $U$-test).

nitrogen isotope ratios were the same as those reported by Minagawa et al. (1984) and Minami et al. (1995). A quartz tube containing 10 to $20 \mathrm{mg}$ of powdered muscle, $1 \mathrm{~g}$ of $\mathrm{CuO}, 0.5 \mathrm{~g} \mathrm{Cu}$ and a piece of silver foil was evacuated, sealed, preheated at $500^{\circ} \mathrm{C}$ for $30 \mathrm{~min}$, and combusted at $850^{\circ} \mathrm{C}$ for $2 \mathrm{~h}$. After cooling overnight, $\mathrm{CO}_{2}$ and $\mathrm{N}_{2}$ were separated cryogenically with a dry ice-ethanol mixture and liquid nitrogen. Carbon and nitrogen isotope ratios were measured with Finnigan MAT 251 and Delta-S mass spectrometers fitted with dual inlet and triple collector systems. Isotope ratios were expressed as \% deviations from standards as defined by the following equation:

$$
\delta^{13} \mathrm{C}, \delta^{15} \mathrm{~N}=\left(\mathrm{R}_{\text {sample }} / \mathrm{R}_{\text {standard }}-1\right) \cdot 1000(\%)
$$

where $\mathrm{R}={ }^{13} \mathrm{C} /{ }^{12} \mathrm{C}$ or ${ }^{15} \mathrm{~N} /{ }^{14} \mathrm{~N}$. Peedee belemnite and atmospheric nitrogen were used as the carbon and nitrogen isotope standards, respectively. Standard deviations for stable isotope measurements were always less than $0.1 \%$ for carbon and $0.2 \%$ for nitrogen.

\section{RESULTS}

\section{Longitudinal variations in stable carbon and nitrogen isotope ratios of sooty shearwaters after northward migration}

There were longitudinal variations in $\delta^{13} \mathrm{C}$ and $\delta^{15} \mathrm{~N}$ of sooty shearwaters that arrived in the Northern Hemisphere in May and June (Fig. 2). The difference in $\delta^{15} \mathrm{~N}$ values between immature birds sampled from
The mean $\delta^{13} \mathrm{C}$ values of mature birds in the northwestern and northeastern areas were $-20.2 \pm 1.1$ and $-19.6 \pm 0.8 \%$, respectively, while the mean $\delta^{1.5} \mathrm{~N}$ values were $9.4 \pm 1.1$ and $10.8 \pm 1.5 \%$, respectively, with a wide overlap ( $\mathrm{C}: \mathrm{p}>0.05 ; \mathrm{N}$ : p > 0.05; Mann-Whitney $U$-test). The changes in the $\delta^{13} \mathrm{C}$ and $\delta^{15} \mathrm{~N}$ values of mature birds with longitude were insignificant in contrast to those of immature birds

No significant differences in the $\delta^{13} \mathrm{C}$ and $\delta^{15} \mathrm{~N}$ values between mature and immature birds existed in the northwestern area (C: $\mathrm{p}>0.05 ; \mathrm{N}: \mathrm{p}>0.05$; MannWhitney $U$-test), while in the northeastern area, the carbon and nitrogen isotopes in muscle tissue of the immature birds were higher than those of mature birds (C: $p<0.001 ; \mathrm{N}: \mathrm{p}<0.001 ;$ Mann-Whitney $U$-test). The variations in $\delta^{13} \mathrm{C}$ and $\delta^{15} \mathrm{~N}$ of the sooty shearwaters across longitude $170^{\circ} \mathrm{W}$ may reflect differences in prey selection or variation in oceanographic factors.

\section{Seasonal variations in stable carbon and nitrogen isotope ratios of sooty shearwaters in the northwestern and northeastern Pacific}

In the northwestern Pacific, the $\delta^{13} \mathrm{C}$ and $\delta^{15} \mathrm{~N}$ values of both mature and immature birds were lowest in May (both mature and immature: $\delta^{13} \mathrm{C}-20.7 \pm 0.9 \%, \delta^{15} \mathrm{~N}$ $8.8 \pm 1.0 \%$; mean $\pm \mathrm{SD}$ ) and then gradually increased until they plateaued in early summer (Fig. 3; both mature and immature in July: $\delta^{13} \mathrm{C}-18.6 \pm 0.7 \%, \delta^{15} \mathrm{~N}$ $11.6 \pm 1.2 \% ; \mathrm{C}: \mathrm{p}<0.01 ; \mathrm{N}: \mathrm{p}<0.01 ;$ Mann-Whitney $U$ test between May and July). From July to September, 

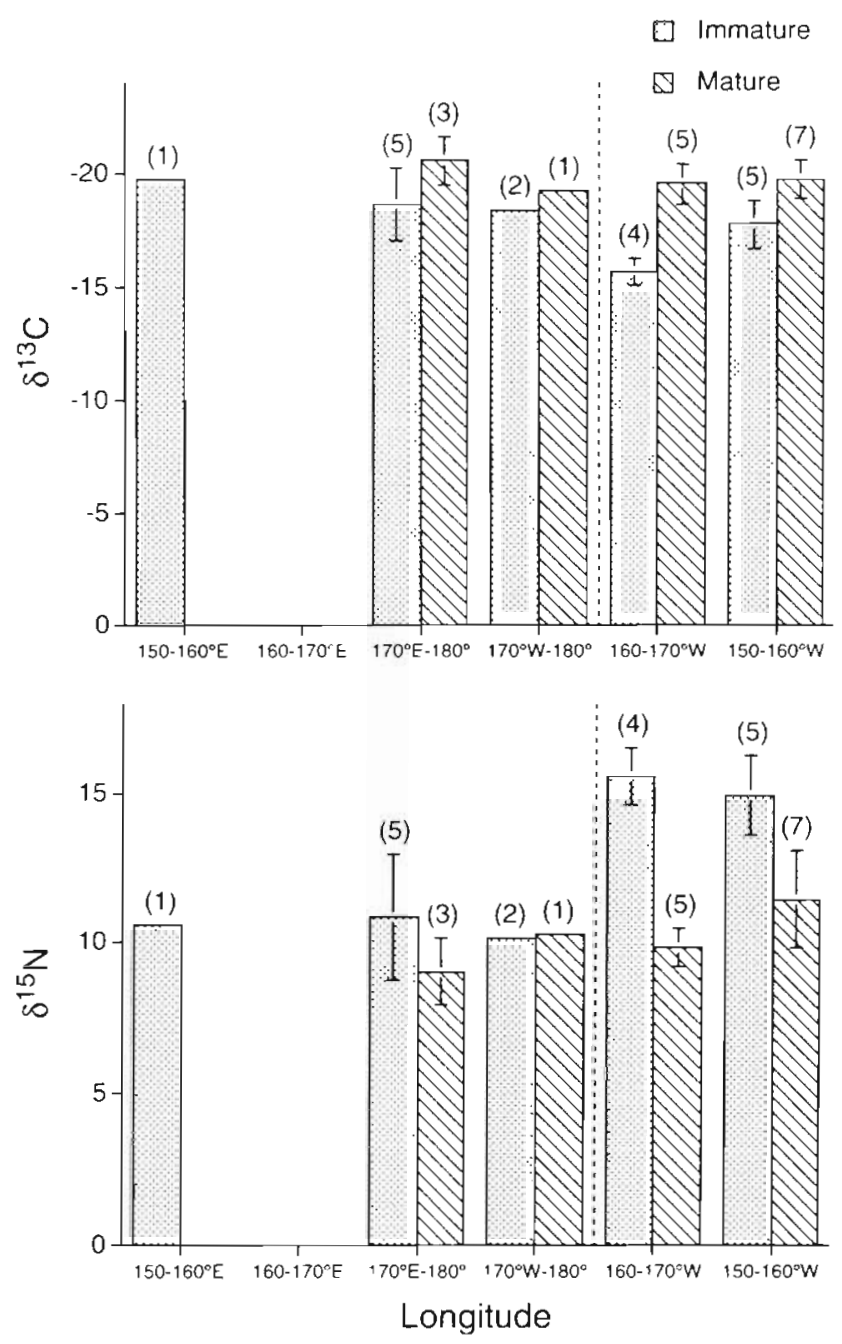

Fig. 2. Puffinus griseus. Longitudinal varıations in $\delta^{13} \mathrm{C}$ and $\delta^{15} \mathrm{~N}$ values $(\%$, mean $\pm \mathrm{SD}$ ) of 2 mmature and mature sooty shearwaters in the North Pacific Dotted line drvides the 2 distınct regions (western and eastern North Pacifıc). Sample sizes given in parentheses

when the birds fed on prey in the North Pacific for over 1 mo after the northward migration, the mean $\delta^{13} \mathrm{C}$ and $\delta^{15} \mathrm{~N}$ values of mature and immature birds in the northwestern area were $-18.7 \pm 0.6$ and $11.6 \pm 1.1 \%$, respectively.

In contrast to the immature burds in the northwestern Pacific, the $\delta^{13} \mathrm{C}$ and $\delta^{15} \mathrm{~N}$ values of immature birds in the northeastern Pacific were the highest during May $\left(\delta^{13} \mathrm{C}-15.9 \pm 0.5 \%, \delta^{15} \mathrm{~N} 15.9 \pm 0.8 \%\right)$ and then gradually decreased (Fig 3; immature in July: $\delta^{13} \mathrm{C}-18.0 \pm$ $1.0 \%, \delta^{15} \mathrm{~N} 13.2 \pm 1.5 \%$; C: $\mathrm{p}<0.05 ; \mathrm{N}: \mathrm{p}<0.05$; MannWhitney $U$-test between May and July). The mean $\delta^{13} \mathrm{C}$ and $\delta^{15} \mathrm{~N}$ values of the immature birds in the northeastern area from July to September, when sooty shearwaters were in the North Paclfic, were $-18.4 \pm 1.0$ and $12.6 \pm 1.5 \%$, respectively, while the corresponding $\delta^{13} \mathrm{C}$ and $\delta^{15} \mathrm{~N}$ values of the mature birds were $-19.4 \pm$ 1.2 and $121 \pm 1.6 \%$, respectively.

\section{DISCUSSION}

The $\delta{ }^{15} \mathrm{~N}$ values of animals in a marine food web increase by about $3.4 \pm 1.1 \%$ per trophic level (Minagawa \& Wada 1984, Wada et al. 1987, 1991, Wada \& Hatton 1991). However, Mizutani et al. (1991) and Hobson \& Clark (1992b) estimated $\delta^{15} \mathrm{~N}$ enrichment values of 2.4 and $1.4 \%$ in muscles of captive common cormorants Phalacrocorax carbo and ring-billed gulls Larus delawarensis, respectively. ${ }^{15} \mathrm{~N}$ enrichments in muscle tissue relative to the diet of piscivorous birds are less than those of other marine organisms (Hobson \& Welch 1992). The $\delta^{13} \mathrm{C}$ values of animals and birds increase about $1 \%$ per trophic level and are very close to those of their diet (DeNiro \& Epstein 1978). The $\delta^{13} \mathrm{C}$ abundance thus indicates $\delta^{13} \mathrm{C}$ values of the available food source (Fry 1988, Hobson \& Welch 1992). In this study, we used a $\delta^{15} \mathrm{~N}$ enrichment value of $2.4 \%$ to estimate the food habits of the sooty shearwater according to the method described by Hobson \& Welch (1992).

The $\delta^{13} \mathrm{C}$ and $\delta^{15} \mathrm{~N}$ values of immature birds of the northeastern population were significantly higher than those in the northwestern population, strongly suggesting that the immature birds in the 2 populations fed on prey with different isotope ratios. Since sooty shearwaters in the western South Pacific are considered to migrate along the western Pacific, whereas the birds in the eastern South Pacific migrate along the eastern Pacific (Shuntov 1972), the observed difference was likely caused by the geographical variation of the stable isotope ratios in the Pacific Ocean. According to Shuntov (1972), the birth place of the population which migrates to the northwestern Pacific is New Zealand or southeastern Australia, while that of the population which migrates to the northeastern Pacific is southern South America. Consequently, 2 main causes for the isotopic differences between the sooty shearwaters sampled in the northwestern and northeastern Pacific can be proposed: differences in prey selection and/or differences in isotopic signatures of food-web components due to the oceanographic factors in the North Pacific.

To examine the influence of prey selection, the stomach contents of the birds sampled in the 2 areas were compared. In the subtropical western Pacific in June, fish (Cololabis saira) was the most important food item in the stomachs of sooty shearwaters by mass $(78.1 \%)$, followed by barnacles (Cirripedia sp., 10.9\%) and jellyfish (Vellela lata, 8.8\%) (Ogi 1984). In the subtropical eastern Pacific from May through July, sooty shearwa- 
Fig. 3. Puffinus griseus. Monthly changes in $\delta^{13} \mathrm{C}$ and $\delta^{15} \mathrm{~N}$ values (\%o, mean $\pm \mathrm{SD}$ ) of immature (E) and mature (O) sooty shearwaters collected from the western and eastern North Pacific. Sample sizes given in parentheses
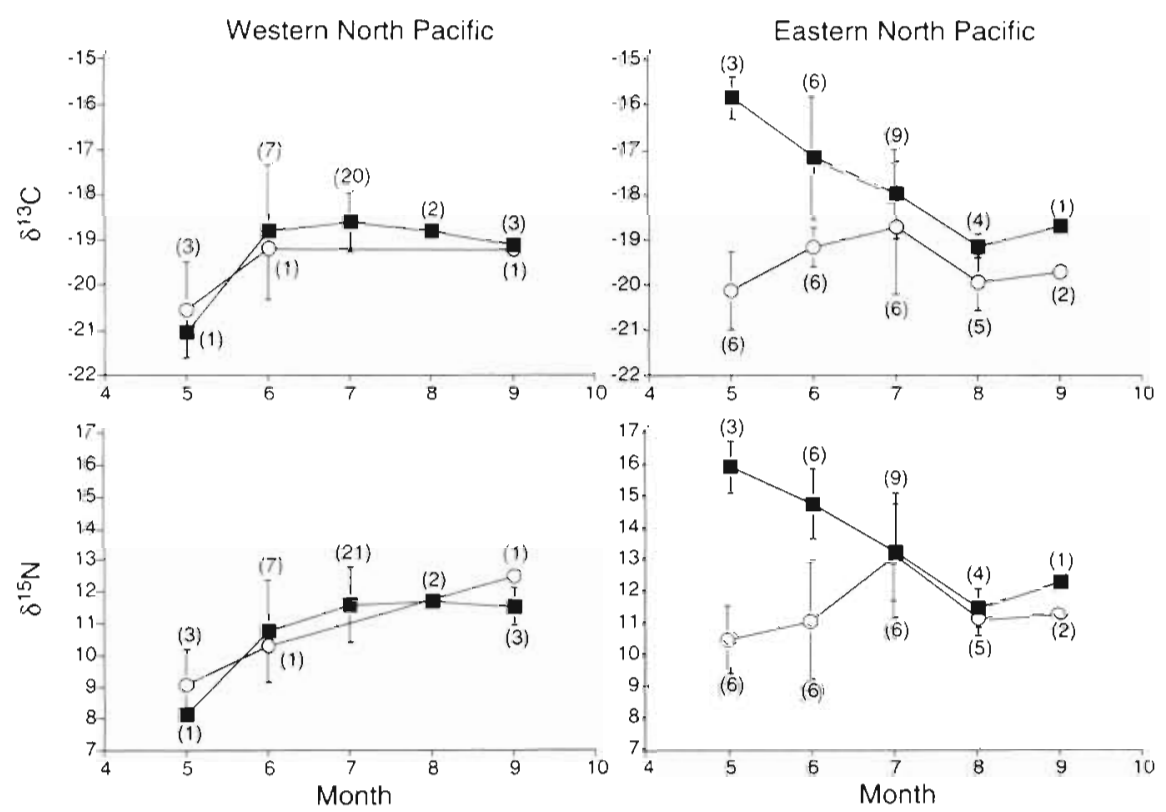

ters fed primarily on juvenile rockfish (Sebastes spp.) and northern anchovy (Engraulis mordax), while squid (Loligo opalescens) and euphausiids (Thysanoessa spinifera) were minor components of the diet (Chu 1984). Shiomi \& Ogi (1992) showed that fish (Sardinops melanosticta, Cololabis saira; $51.4 \%$ ), squid (Berryteuthis anonychus, $30.9 \%$ ) and pelagic barnacles (Lepas fascicularis, $15.2 \%$ ) were the main prey of the birds in the subtropical western and eastern Pacific (approximate longitude $150^{\circ} \mathrm{E}$ to $140^{\circ} \mathrm{W}$ ) in June and July. Japanese sardine, Pacific saury and rockfish constituted the most important prey items for sooty shearwaters in the North Pacific (Chu 1984, Shiomi \& Ogi 1992). Although there were slight differences in shearwater prey selection between the northwestern and northeastern areas, the trophic levels of the prey in the 2 areas were almost identical. The marked differences in sooty shearwater $\delta^{13} \mathrm{C}$ and $\delta^{15} \mathrm{~N}$ values between the northwestern and northeastern Pacific were unlikely to have been caused by differences in prey selection.

To assess the influence of oceanographic factors on food web, $\delta^{13} \mathrm{C}$ and $\delta^{15} \mathrm{~N}$ values of primary producers, sooty shearwater prey and other marine organisms in the North Pacific during spring and summer were summarized (Table 1). Marine organisms in the northwestern feeding area have somewhat lighter isotopes as compared to those in the northeastern area. We predicted the $\delta^{15} \mathrm{~N}$ values of sooty shearwaters by a simple trophic effect of $2.4 \%$, assuming that the birds fed on only 2 species, Pacific saury (Cololabis saira) and a euphausiid.

In the northwestern area, the $\delta^{15} \mathrm{~N}$ value of birds that fed exclusively on either Pacific saury or euphausijds is predicted, by this model, to be 11.6 and $9.8 \%$, respectively, corresponding to the given $\delta^{15} \mathrm{~N}$ value of Pacific saury and euphausiids of 9.2 and $7.4 \%$. In contrast, the $\delta^{15} \mathrm{~N}$ value of sooty shearwaters in the northeastern area feeding on euphausiids exclusively is calculated to be $13.0 \%$, since the $\delta^{15} \mathrm{~N}$ value of the euphausiids there is $10.6 \%$ (Table 1). If the Pacific saury $\delta^{15} \mathrm{~N}$ is 1 to $2 \%$ higher than that of the euphausiids in the northeastern area, as in the northwestern area, then the $\delta^{15} \mathrm{~N}$ value of sooty shearwaters feeding exclusively on Pacific saury would be 14 to $15 \%$.

However, the low $\delta^{13} \mathrm{C}$ and $\delta^{15} \mathrm{~N}$ values for the mature birds in the 2 areas and for the immature birds in the northwestern area in May are clearly different from those predicted by the model for the North Pacific. Furthermore, the isotopic composition of immature birds in the northeastern area in May was heavier than that predicted by the model. Thus, the differences in isotope ratios among the birds in question could not be explained only by the above simple trophic model.

Instead, the low or high $\delta^{13} \mathrm{C}$ and $\delta^{15} \mathrm{~N}$ values might reflect the life history of each population, that is, differences in the isotopic signatures of food-web components due to oceanographic factors of the feeding areas before or during migration. Minami et al. (1995) showed that low stable isotope ratios of sooty and short-tailed (Puffinus tenuirostris) shearwaters on the Pacific coast of northern Japan in April and May had been strongly affected by the isotope ratios of their prey in the Southern Hemisphere before or during their northward migrations. This transient effect could also be taking place in the present case. The low stable 
Table $1 . \delta^{13} \mathrm{C}$ and $\delta^{15} \mathrm{~N}$ values $(\%)$ of marine food-web components in the Pacific Ocean

\begin{tabular}{|c|c|c|c|c|c|}
\hline Samples (n) & $\delta^{13} \mathrm{C}$ & $\delta^{15} \mathrm{~N}$ & Month & Location & Source \\
\hline \multicolumn{6}{|l|}{ Western North Pacific } \\
\hline Particulate organic matter & $-\overline{20.3}$ & $\begin{array}{c}5.4 \\
-\end{array}$ & $\begin{array}{l}\text { Jul } \\
\text { Jun }\end{array}$ & $\begin{array}{l}39^{\circ} 59^{\prime} \mathrm{N}, 138^{\circ} 05^{\prime} \mathrm{E} \\
41^{\circ} 00^{\prime} \mathrm{N}, 142^{\circ} 20^{\prime} \mathrm{E}\end{array}$ & $\begin{array}{l}\text { Sugisaki et al. (1991) } \\
\text { Sugisaki (1989) }\end{array}$ \\
\hline \multicolumn{6}{|l|}{ Euphausia } \\
\hline Euphausia pacifica & -18.4 & 7.4 & Jun & $39^{\circ} 30^{\prime} \mathrm{N}, 147^{\circ} 47^{\prime} \mathrm{E}$ & Minami et al. (1995) \\
\hline \multicolumn{6}{|l|}{ Fish } \\
\hline Engraulis japonicus (1) & -18.7 & 8.9 & Jun & $41^{\circ} 00^{\prime} \mathrm{N}, 155^{\circ} 00^{\prime} \mathrm{E}$ & Minami et al. (1995) \\
\hline Cololabis saira (15) & $-18.5 \pm 0.58$ & $9.2 \pm 0.58$ & Jun & $39^{\circ} 22^{\prime} \mathrm{N}, 155^{\circ} 04^{\prime} \mathrm{E}$ & Minami et al. (1995) \\
\hline \multicolumn{6}{|l|}{ Eastern North Pacific } \\
\hline Particulate organic matter ( 3 ) & $-21.6 \pm 0.2$ & $6.8 \pm 0.1$ & May-Aug & Barkley Sound region & Hobson et al. (1994) \\
\hline \multicolumn{6}{|l|}{ Kelp } \\
\hline Macrocystis integrifolia (3) & $-1.6 .9 \pm 0.3$ & $8.1 \pm 0.4$ & May-Aug & Barkley Sound region & Hobson et al. (1994) \\
\hline Nereocystis luetkena (3) & $-16.7 \pm 0.4$ & $9.3 \pm 0.3$ & May-Aug & Barkley Sound region & Hobson et al. (1994) \\
\hline Egregia menziesii (2) & $-15.6 \pm 0.3$ & $9.0 \pm 0.3$ & May-Aug & Barkley Sound region & Hobson et al. (1994) \\
\hline \multicolumn{6}{|l|}{ Euphausia } \\
\hline Euphausia sp. (5) & $-18.6 \pm 0.4$ & $10.6 \pm 0.6$ & May-Aug & Barkley Sound region & Hobson et al. (1994) \\
\hline
\end{tabular}

isotope ratios of the mature birds in the 2 areas and the immature birds in the northwestern area in May are affected by the isotope ratios of their prey in the Southern Hemisphere before or during their northward migrations. The high $\delta^{13} \mathrm{C}$ and $\delta^{15} \mathrm{~N}$ values of sooty shearwaters in the North Pacific observed after July $\left(\delta^{13} \mathrm{C}:-19\right.$ to $-18 \%$; $\delta^{15} \mathrm{~N}: 12$ to $13 \%$ ) imply that feeding on prey such as euphausiids and Pacific saury with high isotopic values caused the increase in isotopic values of sooty shearwater muscle.
The mean $\delta^{13} \mathrm{C}$ and $\delta^{15} \mathrm{~N}$ values of food-web components in the Antarctic Ocean (around southern South America) were -27.0 and $5.1 \%$ for euphausiids, -25.4 and $6.9 \%$ for squid (Kondakoria longimama), and -23.4 and $10.4 \%$ for fish (Trematomus bernacchir), respectively (Wada et al. 1987). Rau et al. (1992) found that the isotopic values of 12 birds, 4 seals and 4 fish species collected in the Weddell Sea ranged from -31.3 to $-22.0 \%$ for $\delta^{13} \mathrm{C}$ and from 4.4 to $11.2 \%$ for $\delta^{15} \mathrm{~N}$. However, the high $\delta^{15} \mathrm{~N}$ values of immature shearwa-



Fig. 4. Puffinus griseus. Possible migratory routes of immature (dotted line) and mature (solid line) sooty shearwaters in the Pacific Ocean based on stable isotopic analyses. Shaded areas in the tropical eastern Pacific Ocean denote the oxygendeficient upwelling regions where denitrification occurs extensively in the middle layers of the water column. Shaded areas in the tropical western Pacific Ocean indicate the regions where $\mathrm{N}_{2}$-fixing blue-green algae appear dominantly. Numbers in parentheses indicate $\delta^{15} \mathrm{~N}$ values $(\%) . \delta^{15} \mathrm{~N}$ values for mature and immature sooty shearwaters in the Antarctic and the eastern tropical Pacific are from birds sampled in the North Pacific in May. $\delta^{15} \mathrm{~N}$ values of particulate organic matter (POM) or particulate organic nitrogen (PON) are from Saino \& Hattori (1987), Wada et al. (1987), Sugisaki et al. (1991) and Hobson et al. (1994); those of Trichodesmium spp are from Wada \& Hattori (1991) 
ters in the northeastern Pacific cannot be sufficiently explained by the isotopic signatures of those food-web components in southern South America. The high $\delta^{15} \mathrm{~N}$ values of the birds in the northeastern area seem to have a close correlation with the eastern tropical denitrifying zones off Peru and California during their northward migration. The available food-web component $\delta^{15} \mathrm{~N}$ in the eastern tropical Pacific is significantly high. The $\delta^{15} \mathrm{~N}$ value of POM, the first trophic position, in the eastern tropical Pacific was higher than those from other areas (Saino \& Hattori 1987, Liu \& Kaplan 1989). POM $\delta^{15} \mathrm{~N}$ ranges from 6.6 to $14.4 \%$ (Saino \& Hattori 1987), while netplankton $\delta^{13} \mathrm{C}$ and $\delta^{15} \mathrm{~N}$ are - $19.3 \%$ (Degens et al. 1968) and $11.4 \%$ (Libes \& Deuser 1988), respectively. Therefore, the immature birds in the northeastern area might feed on prey with high isotopic values in the eastern tropical area during the northward migration, while mature birds in the same area might not (Fig. 4). The possibility that only mature birds in the northeastern area migrate from New Zealand or southeastern Australia should also be considered.

Recently, Hobson (1993) suggested that $\delta^{13} \mathrm{C}$ analysis was useful in distinguishing benthic and inshore feeding birds from those with pelagic and offshore feeding habits; the $\delta^{13} \mathrm{C}$ of pelagic feeders was lighter than that of benthic feeders. If this conjecture proves to be the case, immature sooty shearwaters perhaps fed on inshore prey during migration because the $\delta^{13} \mathrm{C}$ in the immature birds in the northeastern area was heavier than that in other groups of birds.

Isotopic analyses of migratory seabirds sampled in various locations at different times can provide useful information on their migratory behaviour. In addition to the muscle analyses, isotopic analyses of tissues, such as liver and blood, with quick turnover rates (Hobson \& Clark 1992a, 1993) are also useful for the elucidation of feeding habits over short periods. The stable isotope technique thus provides time series and time-integrated, quantitative information on the feeding habits and migratory mechanisms of the sooty shearwater, which are quite difficult to observe directly on the open ocean.

Acknowledgements. We are grateful to Professor E. Wada, Center for Ecological Research. Kyoto Unversity, for helpful advice and allowing us to use his laboratories at the Mitsubishi Kasei Institute of Life Science and at Kyoto University during this study.

\section{LITERATURE CITED}

Briggs KT, Chu EW (1986) Sooty shearwaters off California: distribution, abundance and habitat use. Condor 88: $355-364$

Chu EW (1984) Sooty shearwaters off California: diet and energy gain. In: Nettleship DN, Sanger GA, Springer PF (eds) Marine birds: their feeding ecology and commercial fisheries relationships. Can Wildl Serv Spec Publ, Ottawa, p 64-71

Cline JD, Kaplan IR (1975) Isotopic fractionation of dissolved nitrate during denitrification in the eastern tropical North Pacific Ocean. Mar Chem 3:271-299

Degens ET, Behrendt M, Gotthardt B, Reppmann E (1968) Metabolic fractionation of carbon isotopes in marine plankton - II. Data on samples collected off the coasts of Peru and Ecuador. Deep Sea Res 15:11-20

DeNiro MJ, Epstein S (1978) lnfluence of diet on the distribution of carbon isotopes in animals. Geochim Cosmochim Acta 42:495-506

DeNiro MJ, Epstein S (1981) Influence of diet on the distribution of nitrogen isotopes in animals. Geochim Cosmochim Acta 45:341-351

Fry B (1988) Food web structure on Georges Bank from stable C, N, and S isotopic compositions. Limnol Oceanogr 33: $1182-1190$

Guzman JR, Myres MT (1983) The occurrence of shearwaters (Puffinus spp.) off the west coast of Canada. Can J Zool 61: $2064-2077$

Hobson KA (1987) Use of stable-carbon isotope analysis to estimate marine and terrestrial protein content in gull diets. Can J Zool 65:1210-1213

Hobson KA (1990) Stable isotope analysis of marbled murrelets: evidence for freshwater feeding and determination of trophic level. Condor 92:897-903

Hobson KA (1991) Stable isotopic determinations of the trophic relationships of seabirds: preliminary investigations of alcids from coastal British Columbia. In: Montevecchi WA, Gaston AJ (eds) Studies of high-latitude seabirds. 1 Behavioural, energetic, and oceanographic aspects of seabird feeding ecology. Can Wildl Serv Occ Pap No. 68, Ottawa, p 16-20

Hobson KA (1993) Trophic relationships among high Arctic seabirds: insights from tissue-dependent stable-isotope models. Mar Ecol Prog Ser 95:7-18

Hobson KA, Clark RG (1992a) Assessing avian diets using stable isotopes I: turnover of ${ }^{13} \mathrm{C}$ in tissues. Condor 94 : $181-188$

Hobson KA, Clark RG (1992b) Assessing avian diets using stable isotopes II: factors influencing diet-tissue fractionation. Condor 94:189-197

Hobson KA, Clark RG (1993) Turnover of ${ }^{13} \mathrm{C}$ in cellular and plasma fractions of blood: implications for nondestructive sampling in avian dietary studies. Auk 110:638-641

Hobson KA, Pratt JF, Pitocchelli J (1994) Using stable isotopes to determine seabird trophic relationships. J Anim Ecol 63: $786-798$

Hobson KA, Welch HE (1992) Determination of trophic relationships within a high Arctic marine food web using $\delta^{13} \mathrm{C}$ and $\delta^{15} \mathrm{~N}$ analysis. Mar Ecol Prog Ser 84:9-18

Libes SM, Deuser WG (1988) The isotope geochemistry of particulate nitrogen in the Peru Upwelling Area and the Gulf of Maine. Deep Sea Res 35:517-533

Liu KK, Kaplan IR (1989) The eastern tropical Pacific as a source of ${ }^{15} \mathrm{~N}$-enriched nitrate in seawater off southern California. Limnol Oceanogr 34:820-830

Marchant S, Higgins PJ (1990) Handbook of Australian, New Zealand \& Antarctic birds, Vol 1, Ratites to ducks, Part A, Ratites to petrels. Oxford Univ Press, Oxford

Minagawa M. Wada E (1984) Stepwise enrichment of ${ }^{15} \mathrm{~N}$ along food chains: further evidence and the relation between $\delta^{15} \mathrm{~N}$ and animal age. Geochim Cosmochim Acta $48: 1135-1140$ 
Minagawa M, Winter DA, Kaplan IR (1984) Comparison of Kjeldahl and combustion methods for measurement of nitrogen isotope ratios in organic matter. Anal Chem 56: $1859-1861$

Minami $H$, Minagawa $M$, Ogi $H$ (1995) Changes in stable carbon and nitrogen isotope ratios in sooty and short-tailed shearwaters during their northward migration. Condor 97 : 565-574

Mizutani H, Fukuda M, Kabaya Y, Wada E (1990) Carbon isotope ratio of feathers reveals feeding behavior of cormorants. Auk 107:400-403

Mizutani H, Kabaya Y, Wada E (1991) Nitrogen and carbon isotope compositions relate linearly in cormorant tissues and its diet. Isotopenpraxis 27:166-168

Ogi $\mathrm{H}$ (1984) Feeding ecology of the sooty shearwater in the western subarctic North Pacific Ocean. In: Nettleship DN, Sanger GA, Springer PF (eds) Marine birds: their feeding ecology and commercial fisheries relationships. Can Wildl Serv Spec Publ, Ottawa, p 78-84

Ogi $H$, Shimazaki K, Nakamura K (1981) Sooty shearwaters in the subarctic North Pacific: seasonal changes in body weight and molt. Res Inst N Pac Fish Hokkaido Univ Sp Vol, p $207-215$

Rau GH, Ainley DG, Bengtson JL, Torres JJ, Hopkins TL (1992) ${ }^{15} \mathrm{~N} /{ }^{14} \mathrm{~N}$ and ${ }^{13} \mathrm{C} /{ }^{12} \mathrm{C}$ in Weddell Sea birds, seals, and fish: implications for diet and trophic structure. Mar Ecol Prog Ser 84:1-8

Richdale LE (1963) Biology of the sooty shearwater Puffinus griseus. Proc Zool Soc Lond 141:1-117

Saino T, Hattori A (1987) Geographical variation of the water column distribution of suspended particulate organic nitrogen and its ${ }^{15} \mathrm{~N}$ natural abundance in the Pacific and its marginal seas. Deep Sea Res 34:807-827

Sanger GA, Ainley DG (1988) Review of the distribution and feeding ecology of seabirds in the oceanic subarctic North

Editorial responsibility: Otto Kinne (Editor),

Oldendorf/Luhe, Germany
Pacific Ocean. Bull Ocean Res Inst Univ Tokyo 26 (Part 2): $161-186$

Schell DM, Saupe SM, Haubenstock N (1989) Natural isotope abundances in bowhead whale (Balaena mysticetus) baleen: markers of aging and habitat usage. In: Rundel PW, Ehleringer JR, Nagy KA (eds) Stable isotopes in ecological research. Springer-Verlag, New York, p $260-269$

Shiomi K (1993) Morphological and ecological studies of sooty shearwater (Puffinus griseus) in the North Pacific. PhD thesis, Hokkaido University, Hokkaido (in Japanese)

Shiomi K, Ogi H (1992) Feeding ecology and body size dependence on diet of the sooty shearwater, Puffinus griseus, in the North Pacific. Proc NIPR Symp Polar Biol 5:105-113

Shuntov VP (1972) Sea birds and biological structure of the ocean (translated from Russian). Nat Tech Inform Serv, US Dept Comm 1974

Sugisaki H (1989) Ecology of the pelagic amphipod Themisto japonica in the Oyashio region and the Sea of Japan. PhD thesis, University of Tokyo (in Japanese)

Sugisaki H, Terazaki M, Wada E, Nemoto T (1991) Feeding habits of a pelagic amphipod, Themisto japonica. Mar Biol 109:241-244

Thompson RC (1953) Studies of metabolic turnover with tritium as a tracer. II. Gross studies on the rat. J Biol Chem 200:731-743

Wada E, Hattori A (1991) Nitrogen in the sea: forms, abundances, and rate processes. CRC Press, Boca Raton

Wada E, Mizutani H, Minagawa M (1991) The use of stable isotopes for food web analysis. Crit Rev Food Sci Nutr 30 . $361-371$

Wada E, Terazaki M, Kabaya Y, Nemoto $\mathrm{T}(1987){ }^{15} \mathrm{~N}$ and ${ }^{13} \mathrm{C}$ abundances in the Antarctic Ocean with emphasis on biogeochemical structure of the food web. Deep Sea Res 34: $829-841$

Submitted: April 30, 1997; Accepted: August 7, 1997

Proofs received from author(s): October 13,1997 